\title{
Preschool wheezing
}

\author{
Francesca Santamaria \\ From 71st Congress of the Italian Society of Pediatrics. Joint National Meeting SIP, SIMGePeD, Study Group \\ on Pediatric Ultrasound, SUP Study Group on Hypertension \\ Rome, Italy. 4-6 June 2015
}

Pediatricians face many challenges when diagnosing wheezing in preschool children. These diagnostic challenges are compounded by variations in the natural history of early stage asthma, which are not fully understood, since early childhood wheezing and asthma are heterogeneous disorders with many phenotypic and variable expressions. Several risk factors related to genetic, prenatal, and postnatal environment are associated with preschool wheezing. Findings from cohort studies have shown that preschool children with wheeze have deficits in lung function at 6 years of age that persisted until early and middle adulthood, suggesting increased susceptibility in the first years of life that might lead to persistent sequelae [1].

Since no standard definition for the type, severity, or frequency of symptoms exist for this age group, clear evidence-based recommendations are lacking. Without adequate guidance, pediatricians are left to make diagnostic and treatment decisions, which can lead to undertreatment of asthmatics and overtreatment of transient wheezers. New guidelines and/or Consensus documents that specifically address the challenges of diagnosing asthma in this particular age group have recently been published, and researchers are actively seeking new methods and techniques through epidemiological studies to assist primary care clinicians in the diagnostic process [2-5].

Treatment of young children with asthma remains poorly defined and very controversial. A study has described the prescribing patterns among primary care physicians in Italy, and concluded that child characteristics alone are not sufficient to explain how physicians decide to prescribe maintenance treatment and which specific therapy to assign [6]. Daily inhaled corticosteroids seem to be the most effective therapy for recurrent wheezing in trials of children with interim symptoms or atopy. Intermittent high-dose inhaled corticosteroids are

Correspondence: santamar@unina.it

Department of Translational Medical Sciences, Section of Pediatrics, Federico II University, Naples, Italy

C 2015 Santamaria This is an Open Access article distributed under the terms of the Creative Commons Attribution License (http:// creativecommons.org/licenses/by/4.0), which permits unrestricted use, distribution, and reproduction in any medium, provided the original work is properly cited. The Creative Commons Public Domain Dedication waiver (http://creativecommons.org/publicdomain/ zero/1.0/) applies to the data made available in this article, unless otherwise stated. effective in moderate-to-severe viral-induced wheezing without interim symptoms. However, the role of corticosteroids in treating acute asthma in young children has been questioned, is currently being carefully evaluated, and requires evidence-based directions [7-9]. The role of leukotriene receptor antagonist is less clear, and should hopefully be evaluated further in larger study groups [10]. Interventions to modify the short-term and long-term outcomes of preschool wheeze should be a research priority.

Published: 30 September 2015

\section{References}

1. Stein RT, Martinez FD: Asthma phenotypes in childhood: lessons from an epidemiological approach. Paediatr Respir Rev 2004, 5(2):155-161.

2. Global Initiative for Asthma Report: Global strategy for asthma management and prevention. 2014, Available at: http://www.ginasthma. org. Accessed May 11, 2015.

3. British Thoracic Society, Scottish Intercollegiate Guidelines Network: British guideline on the management of asthma: a national clinical guideline., Available from: https://www.brit-thoracic.org.uk/document-library/clinicalinformation/asthma/btssign-guideline-on-the-management-of-asthma/. Accessed May 11, 2015.

4. Brand PL, Baraldi E, Bisgaard H, Boner AL, Castro-Rodriguez JA, Custovic A, et al: Definition, assessment and treatment of wheezing disorders in preschool children: an evidence-based approach. Eur Respir J 2008, 32(4):1096-1110.

5. Brand PL, Caudri D, Eber E, Gaillard EA, Garcia-Marcos L, Hedlin G, et al: Classification and pharmacological treatment of preschool wheezing: changes since 2008. Eur Respir J 2014, 43(4):1172-1177. What drives prescribing of asthma medication to preschool wheezing children? A primary care study. Pediatr Pulmonol 2013, 48(12):1160-1170.

7. Weinberger $\mathrm{M}$ : The challenge of treating preschool asthma. J Allergy Clin Immunol 2014, 133(4):1014-1015.

8. Beigelman A, Zeiger RS, Kelly HW, Bacharier LB, Childhood Asthma Research and Education Network of the National Heart, Lung and Blood Institute: The challenge of treating preschool wheezing episodes: the need for evidence-based approaches. J Allergy Clin Immunol 2014, 133(4):1016-1017.

9. Miller EK, Avila PC, Khan YW, Word CR, Pelz BJ, Papadopoulos NG, et al: Wheezing exacerbations in early childhood: evaluation, treatment, and recent advances relevant to the genesis of asthma. J Allergy Clin Immunol Pract 2014, 2(5):537-543.
6. Montella S, Baraldi E, Bruzzese D, Mirra V, Di Giorgio A, Santamaria F, et al: \\ () Biomed Central}


10. Pelkonen AS, Malmström K, Sarna S, Kajosaari M, Klemola T, Malmberg LP, et al: The effect of montelukast on respiratory symptoms and lung function in wheezy infants. Eur Respir J 2013, 41(3):664-670.

doi:10.1186/1824-7288-41-S2-A64

Cite this article as: Santamaria: Preschool wheezing. Italian Journal of Pediatrics 2015 41(Suppl 2):A64.

Submit your next manuscript to BioMed Central and take full advantage of:

- Convenient online submission

- Thorough peer review

- No space constraints or color figure charges

- Immediate publication on acceptance

- Inclusion in PubMed, CAS, Scopus and Google Scholar

- Research which is freely available for redistribution

Submit your manuscript at www.biomedcentral.com/submit 